\title{
PENGENALAN MATEMATIKA REALISTIK KEPADA MASYARAKAT BELAJAR DI
} KELURAHAN IRINGMULYO

\author{
Zahwa Eza Soeseno ${ }^{1)}$, Farida Arsita ${ }^{2)}$, Annisa Ayu Ulil Amri ${ }^{3)}$, Pika Merliza ${ }^{4)}$, Endah \\ Wulantina $^{5)}$, Selvi Loviana ${ }^{6}$ \\ IAIN Metro,Jl. Ki Hajar Dewantara 15 A Metro ${ }^{1,2,3,4,5,6)}$ \\ Pos-el : pikamerliza@metrouniv.ac.id
}

Dikirim: 20,01, 2020

Direvisi: 27,02, 2020

Diterbitkan: 28,02, 2020

\begin{abstract}
Abstrak
Tujuan dari pengabdian ini adalah diharapkan masyarakat belajar jenjang kelas 4 sekolah dasar (SD) di sekitar kawasan tersebut tidak merasa kesulitan lagi dalam memahami pelajaran matematika setelah dikenalkannya pembelajaran yang mengaitkan matematika dengan kehidupan sehari-hari (Matematika Realistik).Pengabdian ini dilaksanakan Pengabdian dilakukan selama 4 kali pertemuan dengan 20 orang siswa. Bertempat di Kelurahan Iringmulyo pada hari Sabtu, 30 November, Minggu 1 Desember dan Sabtu 7 Desember 2019 dan 8 Desember. Materi pengabdian berupa Pengenalan Bangun datar dengan memberi contoh pada kehidupan seharihari.Permasalahan pokok di Kelurahan Iringmulyo yang menjadi latar belakang dari pengabdian ini adalah: (1) kurangnya pemahaman konsep matematika karena pembelajaran di sekolah tidak mengaitkan matematika dengan kehidupan sehari-hari; (2) belum tersedianya tempat bimbingan belajar matematika yang menjadi pendamping pendidikan formal di sekolah; (3) tidak adanya pendidik yang berlatar belakang pendidikan matematika. Pengabdian ini menggunakan pendekatan kualitatif dengan metode desrkiptif. Alat peraga yang digunakan dalam pengabdian ini adalah jajanan tradisional berbentuk segitiga dan tempe. Hasil evaluasi pelaksanaan dari pengabdian masyarakat :1) Presensi kehadiran dan tingkat partisipasi peserta adalah 100\%. 2) Kegiatan pengabdian ini terlaksana dengan baik sesuai dengan jadwal yang telah ditentukan. 3) Pada akhir pelaksaan pengabdian, masyarakat belajar pada jenjang sekolah dasar (SD) mendapatkan pengetahuan baru dan pengalaman belajar matematika dengan menggunakan Matematika Realistik (MR). 4) Pembelajaran menggunakan Matematika Realistik (MR) meningkatkan minat dan keingintahuan siswa terhadap matematika. 5) Dengan digunakannya pembelajaran Matematika Realistik (MR), pemahaman siswa tentang matematika menjadi lebih mudah, sehingga matematika tidak lagi dianggap sulit. 6) Proses pembelajaran menjadi lebih berwarna dan berarti dengan digunakannya pembelajaran Matematika Realistik (MR). 7) Masyarakat belajar merasa matematika adalah pelajaran yang menyenangkan dilihat dari keantusiasan mereka saat proses pembelajaran sedang berlangsung.
\end{abstract}

Kata Kunci: Matematika Realistik, Masyarakat Belajar

\section{PENDAHULUAN}

Jalan Tongkol, Iringmulyo, Kecamatan Metro Timur, Kota Metro, Lampung merupakan kawasan yang menjadi tempat dalam pengabdian ini. Kawasan ini merupakan daerah strategis 
yang dikelilingi oleh sejumlah lembaga pendidikan dari sekolah dasar hingga perguruan tinggi negeri dan swasta, tempat yang digunakan untuk memberikan pengajaran dasar-dasar Islam dan membaca Al-Qur'an seperti TPA/TPQ yang jumlahnya tidak kurang dari 3 TPA/TPQ, serta satu PUSKESMAS (Pusat Kesehatan Masyarakat) yang memberikan pelayanan di bidang kesehatan.

Di kawasan ini terdapat masyarakat belajar, yang merupakan kumpulan siswa dengan berbagai latar belakang pendidikan mulai dari PAUD hingga perguruan tinggi. Di sekitar kawasan pengabdian, kumpulan siswa yang paling banyak adalah siswa yang sedang menempuh pendidikan pada jenjang Sekolah Dasar (SD) kelas 4, untuk itu subjek ini dipilih sebagai subjek pengabdian. Masyarakat belajar dalam kategori ini telah terpenuhi pendidikan dalam hal pendidikan formal dan agama dengan banyaknya lembaga pendidikan terkait yang memadai. Pada jenjang Sekolah Dasar (SD) cukup strategis dalam mencapai amanat pemerintah di bidang pendidikan (Toyiba, 2016). Namun dalam hal pendidikan akademik yang terkait untuk menunjang pemahaman konsep belum tersedia dengan baik.Sedangkan pembelajaran di sekolahsekolah dasar masih belum memperhatikan pentingnya pemahaman konsep, padahal seharusnya hal tersebut lebih ditekankan (Soviawati, 2011).Saat pembelajaran di sekolah, materi pelajaran tidak dikaitkan dengan kehidupan sehari-hari sehingga siswa merasa kesulitan dan kurang tertarik menerimanya. Masyarakat belajar mengatakan bahwa pendidikan akademik pendamping penting, karena dapat membantu meningkatkan pemahaman saat berlangsungnya proses pembelajaran di sekolah sehingga hasil belajar akan lebih optimal. Hal ini akan membantu siswa dalam memahami pelajaran terlebih untuk pelajaran matematika yang dirasa sulit.

Masyarakat belajar mengakui belum tersedianya tempat seperti bimbingan belajar untuk pelajaran matematika jenjang sekolah dasar dikarenakan tidak adanya pendidik yang memiliki latar belakang pendidikan matematika.Dikarenakan tidak adanya pendidik, masyarakat belajar di sekitar kawasan ini merasa kesulitan dalam memahami matematika jika hanya mendapat pembelajaran formal di sekolah.Padahal matematika merupakan ilmu yang memiliki peranan penting dalam setiap disiplin ilmu.

Matematika menjadi ilmu wajib dan mendapat perhatian khusus karena berguna dalam penguasaan teknologi dan ilmu pengetahuan yang berkembang pesat untuk masa sekarang dan masa yang akan datang. Dengan adanya matematika masalah-masalah kehidupan sehari-hari baik yang sederhana hingga yang kompleks dapat terselesaikan. Hal ini sejalan dengan fungsi matematika yang dapat mengembangkan kemampuan bernalar, sebagai alat pemecahan masalah, 
serta sebagai alat komunikasi (Depdiknas, 2003). Oleh karena itu, pendidikan di Indonesia sangat menekankan penguasaan ilmu eksak ini agar dapat bersaing di era globalisasi.

Dengan pembelajaran matematika, cara berpikir siswa diharapkan mampu berkembang dengan baik karena matematika mempunyai struktur dan keterkaitan yang kuat dan jelas antara konsep-konsep (Wibowo, 2017). Menurut Jenning dan Dunne (1999) dalam jurnal (Soviawati, 2011),mengatakan bahwa, mayoritas siswa mengalami kesulitan dalam mengaplikasikan matematika ke dalam situasi kehidupan real. Hal ini karena siswa-siswa hanya terpaku pada keadaan yang ada di buku dan tidak melihat dunia lingkungannya.

Menurut Ikashaum dan Yunarti, (2019), salah satu kesulitan dalam mempelajari matematika adalah rendahnya kemampuan siswa dalam mengaplikasikan materi matematika dengan kehidupan real. Dalam hal ini guru kurang memberi kesempatan pada siswa untuk mencari ide-ide yang biasa tertuang dalam pikirannya (Merliza dan Retnawati, 2018). Siswa yang hanya terpaku pada satu sumber dan tidak menggali jawaban permasalahan cenderung memiliki kepercayaan diri yang rendah terhadap permasalahan yang diberikan.

Oleh karena itu sangat dibutuhkan pembelajaran yang berorientasi untuk menjembatani antara ilmu matematika dengan minat menanggapi pelajaran. Selain itu, diperlukan juga pembelajaran matematika yang memberikan muatan untuk menjembatani antara matematika dalam dunia sehari-hari yang berbasis pada budaya lokal dengan matematika sekolah (Wulantina \& Maskar, 2019).

Pada tingkat dasar matematika yang bersifat abstrak, lebih baik disajikan dari hal-hal yang konkret ke hal-hal yang abstrak mengingat kemampuan kognitif manusia juga bergerak dari yang konkret ke abstrak (Khabibah dalam Nalole, 2008).Salah satu cara untuk melatih pemahaman matematika siswa dengan baik yakni dengan menggunakan pembelajaran Matematika Realistik. Matematika Realistik dapat membantu pembelajaran matematika agar dapat diaplikasikan dalam kehidupan nyata.

Menurut Siahaan (2006), "realistic mathematics education (RME) adalah teori belajar mengajar dalam pendidikan matematika". Menurut Dickinson \& Hough (2012), "The philosophy underpinning Realistic Mathematics Education (RME) is that students should develop their mathematical understanding by working from contexts that make sense to them." Siahaan (2006) juga mengatakan bahwa salah satu pembelajaran matematika yang memiliki kecenderungan mematematikakan pengalaman sehari-hari dan menerapkan matematika dalam kehidupan sehari- 
hari adalah pembelajaran Matematika Realistik (MR).Dalam era globalisasi dimana teknologi sangat menguasai kehidupan, harus dilakukan hal yang membantu perubahan didunia pendidikan. Untuk itu, dengan pembelajaran matematika secara realistik dapat membantu memahami permasalahan yang ada dalam kehidupan. Untuk mencapai tujuan pendidikan matematika yang lebih baik, matematika realistik penting untuk diterapkan karena dapat melancarkan proses pembelajaran matematika (Holisin, 2007).

Berdasarkan analisis situasi, dapat diketahui bahwa permasalahan pokok yang terjadi di sekitar kawasan ini yaitu: (i) kurangnya pemahaman konsep matematika karena pembelajaran di sekolah tidak mengaitkan matematika dengan kehidupan sehari-hari; (ii) belum tersedianya tempat bimbingan belajar matematika yang menjadi pendamping pendidikan formal di sekolah; (iii) tidak adanya pendidik yang berlatar belakang pendidikan matematika.

Berdasarkan permasalahan pokok di atas, pengabdi merasa perlu melakukan pengabdian untuk masyarakat belajar tingkat kelas 4 sekolah dasar (SD) di sekitar kawasan tersebut.Hasil dari pengabdian ini adalah diharapkan masyarakat belajar jenjang sekolah dasar di sekitar kawasan tersebut tidak merasa kesulitan lagi dalam memahami pelajaran matematika setelah dikenalkannya pembelajaran yang mengaitkan matematika dengan kehidupan sehari-hari (Matematika Realistik).

\section{METODE PENGABDIAN}

Pengabdian ini menggunakan pendekatan kualitatif dengan metode desrkiptif karena secara umum merupakan strategi yang dapat memberi pemahaman kepada siswa dengan mengeksplorasi hal-hal dalam kehidupan sehari-hari.Teknik pengumpulan data yang digunakan dalam pengabdian ini adalah melalui observasi, wawancara dan dokumentasi.

Adapun subyek pengabdiannya yakni masyarakat belajar pada tingkat kelas 4 Sekolah Dasar (SD). Wawancara yang dilakukan melibatkan beberapa siswa yang berlangsung saat proses pembelajaran. Observasi dilaksanakan sebelum pengabdian dan saat proses pembelajaran berlangsung. Dokumentasi didapatkan dari pengambilan gambar saat proses pembelajaran.

Analisis data yang digunakan yakni model Analysis Interactive dari Miles dan Huberman (1994: 12) yang telah membagi kegiatan analisis menjadi beberapa aspek yaitu: pengumpulan data, reduksi data, penyajian data, dan penarikan kesimpulan atau verifikasi data (Putri, 2016). Pengabdian ini akan memberikan tentang pengenalan Matematika Realistik (MR) dalam kehidupan. Proses pelaksanaan pembelajaran di masyarakat belajar ini terbagi dalam tiga tahapan 
yaitu persiapan, pelaksanaan dan evaluasi.

\section{HASIL DAN PEMBAHASAN}

Pembahasan hasil pembelajaran ini dijelaskan berdasarkan tahapan-tahapan kegiatan yang dilakukan yaitu:

\section{Persiapan}

Pada proses persiapan ini, pertama-tama dilakukan observasi di lapangan. Observasi dilakukan mencari kawasan yang sesuai untuk dilakukan pengabdian. Setelah menemukan kawasan yang cocok, pengabdi meminta izin kepada pihak yang memiliki wewenang di kawasan masyarakat belajar Iringmulyo sekaligus menginformasikan kepada masyarakat setempat bahwasanya akan diadakan pengabdian kepada masyarakat belajar siswa kelas 4 sekolah dasar (SD).

Kemudian pengabdi mempersiapkan materi yang akan disampaikan saat pembelajaran nanti. Pengabdi mencari informasi materi yang sedang dibahas di sekolah agar saat pengabdian, materi yang diberikan sejalan dengan yang diajarkan di sekolah.Dengan demikian, lebih mudah membangun pemahaman dan tidak membuat masyarakat belajar bingung dengan materi yang akan disampaikan.

Tahapan selanjutnya, pengabdimembuat konsep pembelajaran dan menyiapkan alat peragasebagai salah bentuk pembelajaran Matematika Realistikyang akan digunakan saatpengabdian. Alat peraga yang dipilih untuk mengenalkan matematika dan diharapkan mampu membuat masyarakat belajar tidak lagi merasa kesulitan memahami matematika adalah alat peraga yang sejalan dengan materi yang sedang dipelajari di sekolah dan dapat menarik minat belajar.Alat peraga ini sangat dibutuhkan untuk memperkenalkan matematika pada siswa karena berkaitan dalam kehidupan sehari-hari.Bentuk-bentuk yang dipilih sebagai alat peraga adalah yang mewakili bentuk segitiga dan jajargenjang. Alat peraga yang digunakan dalam pengabdian ini adalah jajanan tradisional berbentuk segitiga dan tempe. Alat peraga yang diberikan sesuai kriteria alat peraga yang baik menurut Sundayana (Disnawati \& Haning, 2019) diantaranya menarik, sederhana, sesuai dengan konsep materi, menjadi dasar tumbuhnya konsep abstrak bagi anak, serta menjadikan belajar menjadi aktif dan mandiri.

\section{Pelaksanaan}

Pelaksanaan pengabdian masyarakat yang pertama dilakukan pada Sabtu, 30 November 
2019 sekitar pukul 16.00 WIB dengan 20 orang siswa. Masyarakat belajar diminta untuk duduk membentuk lingkaran agar mempermudah pembelajaran. Kemudian dimulai sesi pengenalan diri yang dimulai dari pengabdi. Hal ini dilakukan agar mengenal dan membentuk keakraban satu sama lain.

Masyarakat belajar diminta untuk memberi penjelasan tentang bangun datar dan memberi contoh dalam kehidupan sehari-hari. Dengan bersahutan mereka menjawab "persegi, persegi panjang, jajargenjang, layang-layang, segitiga dan lain sebagainya." Pengabdi memancing pertanyaan pada masyarakat belajar untuk menyebutkan contoh bangun datar dalam kehidupan atau yang ada di sekitar kita. Kali ini, masyarakat belajar yang berhasil menjawab dengan cepat dan benar akan mendapat hadiah berupa makanan ringan untuk menambah kemampuan berpikirnya.

Selanjutnya, pengabdi lebih spesifik dalam memberi penjelasan mengenai bangun segitiga dan juga ciri-cirinya. Segitiga yang memiliki sisi tiga buah dan sudut-sudutnya bahkan jenisjenis dari segitiga. Ada masyarakat belajar yang mencatat tentang penjelasan pengabdi dan ada juga yang tidak mencatatatnya. Setelah diberi penjelasan, siswa diminta mejelaskan kembali ciriciri dari segitiga dan jenis-jenisnya. Masyarakat belajar yang bisa menjelaskan kembali akan mendapatkan hadiah.

Pelaksanaan hari kedua dilakukan pada Minggu, 1 Desember 2019. Masyarakat belajar diminta untuk menyebutkan hal apa saja yang telah dipelajari pada pembelajaran kemarin. Ternyata, masyarakat belajar masih ingat dengat pembelajaran yang lalu. Untuk melanjutkan materi selanjutnya yakni mencari keliling dan luas dari bangun segitiga. Pertama, masyarakat belajar diminta menggambar pentuk persegi panjang dan diminta menulis identitas dari sisisisinya. Sisi AB sebagai panjang persegi panjang dan AC sebagai lebarnya. Setelah itu, bangun persegi panjang $\mathrm{ABCD}$ di potong menjadi dua di garis $\mathrm{AD}$, dan ternyata membentuk dua buah segitiga siku-siku yang sama besarnya. Dalam hal ini, masyarakat telah mengetahui keliling dari bangun datar tersebut dengan cara penjumlahan.

Untuk mencari luas dari segitiga,pengabdi membawa jajanan tradisional yang membentuk bangun segitiga agar terlihat lebih nyata. Masyarakat belajar diminta fokus pada salah satu segitiga misalnya segitiga ABC. Karena bangun datar segitiga terbentuk dari bangun persegipanjang yang dibagi dengan memotong diagonalnya, maka rumus luas segitiga yaitu $\mid \frac{1}{2} \times p \times l$ atau $\frac{1}{2} \times u \times \tau$. Tak disangka, masyarakat belajar memperhatikan dengan seksama apa 
yang dijelaskan oleh pengabdi.

Pelaksanaan hari ketigapengabdian ini, dilakukan pada hari Sabtu,7 Desember 2019 sekitar pukul 16.00 WIB dengan 20 orang siswa. Sebelum memulai pelajaran, pengabdimeminta masyarakat belajar untuk duduk membentuk lingkaran bersama dengannya.Karena pengenalan individu telah dilakukan pada hari pertama maka pembelajaran langsung dilanjutkan.

Pembelajaran diawali dengan menggambarkan bentuk jajargenjang sebagai pengenalan materi.Setelah masyarakat belajar mengetahui bentuk jajargenjang, pengabdi meminta mereka untuk menyebutkan benda di kehidupan sehari-hari yang memiliki bentuk jajargenjang. Diberi waktu 5 menit untuk berfikir dan akan dipilih satu orang siswa yang mengangkat tangannya paling awal.

Saat waktu yang diberikan hampir habis, ada lebih dari 15 siswa yang mengangkat tangan berebutan untuk menjawab.Kemudian dipilih satu yang tercepat dan diminta untuk menyampaikan jawabannya.Siswa tersebut menjawab benda di sekitar yang bentuknya jajargenjang adalah atap rumah.Karena banyak siswa yang masih belum paham maksudnya, siswa yang menyebutkan jawabannya tadi pun diminta untuk menggambarkan bentuk atap yang dimaksud pada buku tulis dan menunjukkan ke teman-temannya.Siswa tersebut pun diberikan hadiah berupa biskuit coklat dengan tulisan penguatan.

Dengan banyaknya siswa yang mengangkat tangan, dianggap sebagai tanda bahwa merekatelah paham dengan bentuk jajargenjang. Kemudian, akan diberikan pemahaman tentang pengertian jajargenjang dengan mengidentifikasikan penyusun jajargenjang. Dengan arahan pengabdi dan bantuan gambar jajargenjang yang diberi nama jajargenjang $\mathrm{ABCD}$, proses identifikasi dimulai dengan melihat pasangan sisi berhadapan yang sejajar.

Pengabdi meminta masyarakat belajar menyebutkan pasangan sisi berhadapan yang sejajar dan mereka pun berebutan utuk menjawab. Ada yang menjawab $\mathrm{AB} / / \mathrm{BC}, \mathrm{AB} / / \mathrm{CD}, \mathrm{BC} / / \mathrm{AD}$, dan masih banyak lagi. Kemudian diberitahu bahwa jawaban yang benar adalah $\mathrm{AB} / / \mathrm{CD}$ dan $A D / / B C$. Setelah itu pengabdi meminta masyarakat belajar untuk memperhatikan panjang $\mathrm{AB} / / \mathrm{CD}$ dan $\mathrm{AD} / / \mathrm{BC}$. Diberi pertanyaan, "apakah pasangan $A B$ dan $C D$ serta $A D$ dan $B C$ memiliki panjang yang sama?" dan mereka pun serempak menjawab iya. Dari sini, pengabdi meminta masyarakat belajar untuk menyimpulkan pengertian jajargenjang. Sama seperti sebelumnya, diberi waktu 5 menit untuk menyusun kalimat yang tepat dan akan dipilih satu orang tercepat mengangkat tangan. Saat pengabdi baru saja selesai memberikan perintah, sudah 
ada banyak siswa yang mengangkat tangannya.Pengabdi pun memilih satu yang tercepat dan meminta untuk menyebutkan jawabannya.Siswa tersebut menjawab, "jajargenjang adalah bangun datar yang memiliki dua pasang sisi sejajar yang sama panjang”.Jawaban siswa tadi sudah benar namun kurang lengkap, jadi pengabdi memberikan petunjuk dengan menanyai ada berapa segi pada bangun datar ini dan memberi kesempatan kepada siswa lain yang ingin melengkapi. Ada banyak siswa yang mengangkat tangannya, dan dipilih satu yang tercepat.Siswa tersebut melengkapi pernyataan temannya, bahwa jajargenjang adalah bangun datar segiempat yang memiliki dua pasang sisi sejajar sama panjang. Karena jawaban siswa tersebut sudah tepat, pengabdi mengajak masyarakat belajar untuk bersama-sama menyebutkan kesimpulan dari pengertian jajargenjang. Kemudian dua siswa yang telah mengutarakan jawabannya diberi hadiah yang sama seperti siswa pertama.

Hari keempat pengabdian yang dimulai pada Minggu, 8 Desember 2019 pukul 09.00 WIB juga dihadiri oleh semua siswa. Pada hari kedua ini, diulas kembali tentang jajargenjang yang telah dipelajari hari sebelumnya dan ditanyakan pada masyarakat belajar apakah ada yang ingin menyebutkan apa pengertian jajargenjang. Masyarakat belajar antusias ingin menjawab dengan mengangkat tangannya tinggi-tinggi dan saling bersautan.Kemudian dipilih siswa secara acak untuk menyebutkan jawabannya, lalu diberikan hadiah setelah selesai menjawab.

Pembelajaran hari kedua ini diawali dengan memperlihatkan alat peraga berupa sebuah tempe yang telah di buat bentuk jajargenjang. Untuk mengetahui bagaimana mencari keliling tempe, masyarakat belajar diberi tahu bahwa yang namanya keliling jajargenjang adalah panjang lintasan yang mengelilingi bentuk jajargenjang. Untuk menguji apakah masyarakat belajar telah paham apa yang dimaksudkan, pengabdi memberikan kesempatan satu orang siswa untuk menunjukkan dan menjelaskan mana yang disebut keliling lingkaran dengan alat peraga tempe. Banyak siswa yang mengajukan dirinya untuk menjawab pertanyaan tersebut dan dipilih satu orang secara acak.Siswa tersebut menunjukkan dan menjelaskan mana yang disebut keliling jajargenjang.Kemudian siswa tersebut diberikan penghargaan berupa hadiah. Setelah dirasa paham dengan apa yang dimaksud keliling jajarrgenjang, pelajaran dilanjutkan memahami apa yang dimaksud dengan luas jajargenjang. Untuk membuat mereka paham dengan apa yang dimasud dengan luas jajargenjang, diberi tahu bahwa satu buah jajargenjang dibentuk oleh dua buah segitiga yang memiliki bentuk dan ukuran yang sama. Hal ini dibuktikan dengan membelah tempe menjadi dua bagian sehingga terlihat dua buah segitiga yang memiliki bentuk dan ukuran 
yang sama. Karena satu buah tempe yang berbentuk jajargenjang sama dengan dua buah segitiga tempe yang memiliki bentuk dan ukuran yang sama. Ini berarti bahwa luas jajargenjang tempe sama dengan dua kali luas segitiga tempe atau jumlah dari luas kedua segitiga tempe.

Untuk mengetahui apakah masyarakat belajar telah paham dengan apa yang dimaksudkan, pengabdi memberikan pertanyaan, "jika luas satu buah segitiga tempe adalah $1 / 2$ (u.t), maka berapakah luas jajargenjang?". Ternyata masyarakat belajar telah paham dengan apa yang dimaksudkan dengan besarnya antusias mereka untuk menjawab dengan menunjuk tangannya dan saling bersautan. Akhirnya ditunjuk satu orang siswa secara acak untuk menjawab. Siswa tersebutpun menjawab, "kan tadi satu buah tempe jajargenjang sama dengan dua buah tempe segitiga, jadi kalo satu segitiga luasnya $1 / 2$ (u.t), luas satu jajargenjang sama dengan dua kali luasnya segitiga tempe tadi. Jadi, jawabannya $2 \times 1 / 2(a)=a$.

Dengan banyaknya antusias dan benarnya jawaban siswa tersebut, maka pelajaran dengan alat peraga tempe ini dinyatakan berhasil.

\section{Evaluasi}

Hasil evaluasi pelaksanaan dari pengabdian masyarakat :

1. Presensi kehadiran dan tingkat partisipasi peserta adalah $100 \%$.

2. Kegiatan pengabdian ini terlaksana dengan baik sesuai dengan jadwal yang telah ditentukan.

3. Pada akhir pelaksaan pengabdian, masyarakat belajar pada jenjang sekolah dasar (SD) mendapatkan pengetahuan baru dan pengalaman belajar matematika dengan menggunakan Matematika Realistik (MR).

4. Pembelajaran menggunakan Matematika Realistik (MR) meningkatkan minat dan keingintahuan siswa terhadap matematika.

5. Dengan digunakannya pembelajaran Matematika Realistik (MR), pemahaman siswa tentang matematika menjadi lebih mudah, sehingga matematika tidak lagi dianggap sulit.

6. Proses pembelajaran menjadi lebih berwarna dan berarti dengan digunakannya pembelajaran Matematika Realistik (MR).

7. Masyarakat belajar merasa matematika adalah pelajaran yang menyenangkan dilihat dari keantusiasan mereka saat proses pembelajaran sedang berlangsung. 


\section{Volume 3, Nomor 1, Februari 2020}
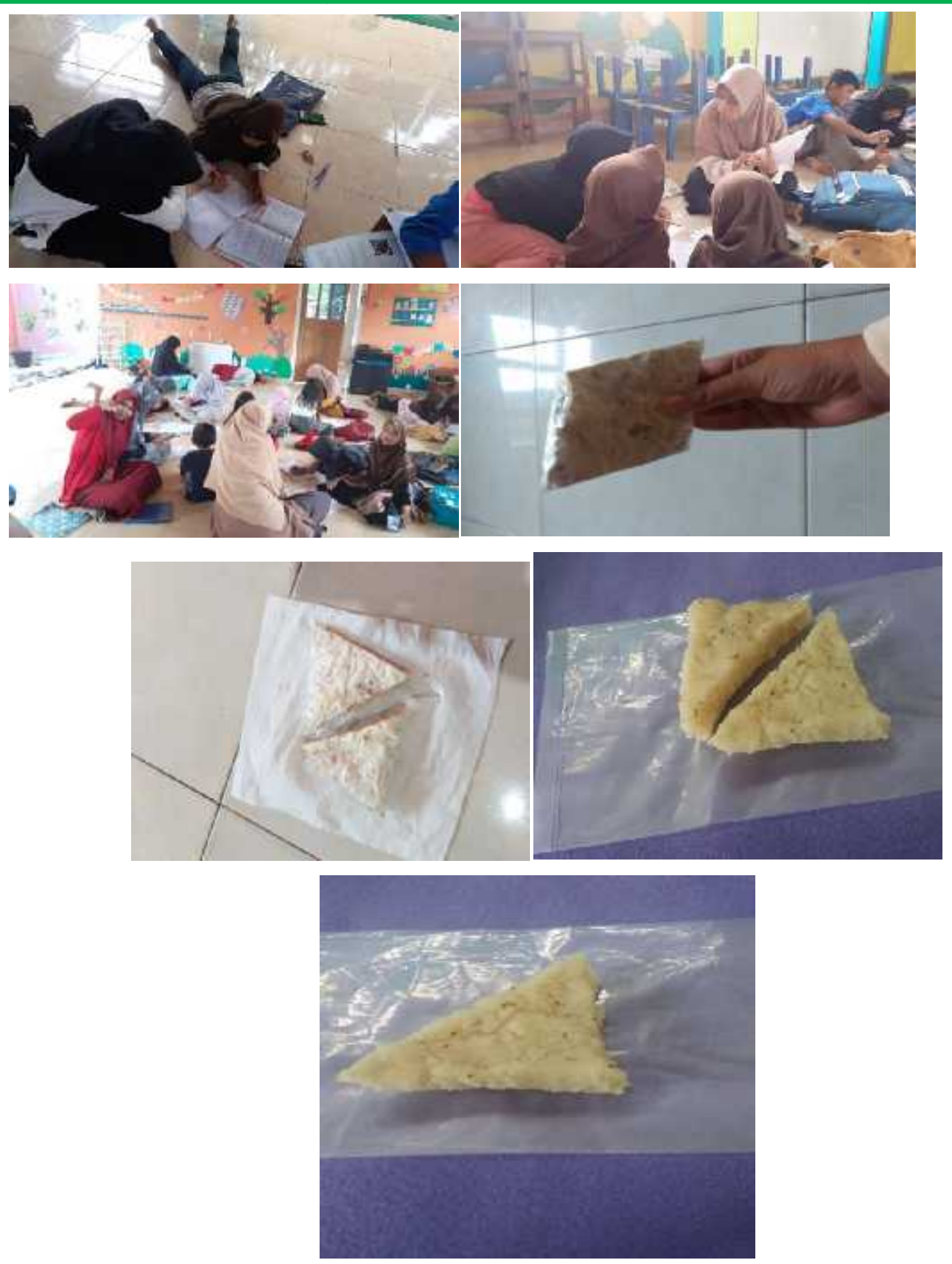

Gambar: Pemaparan materi oleh pengabdi dan media pembelajaran yang digunakan 


\section{KESIMPULAN DAN SARAN}

\section{Simpulan}

Berdasarkan pengabdian yang telah kami lakukan dapat disimpulkan bahwa Pembelajaran matematika secara realistik dapat memperkenalkan siswa-siswa ada materi-materi pembelajaran matematika.Memperkenakan hal-hal disekitar dan mengaitkan dengan pendidikan matematika mampu meningkatkan ketertarikan mereka dan rasa ingintahunya.

\section{Saran}

Pembelajaran melalui pendekatan realistik diharapkan dapat dikembangkan pada materi lain agar dapat menarik minat siswa belajar matematika dalam meningkatkan hasil pembelajarannya. Pembelajaran melalui pendekatan realistik harus tereksplorasi dengan baik oleh guru SD agar menjadi alternatif pembelajaran yang dapat meningkatkan hasil belajar siswa pada materi bangun datar.

\section{DAFTAR PUSTAKA}

Depdiknas. (2003). Standar Kompetensi Mata Pelajaran Matematika.

Dickinson, P., \& Hough, S. (2012). Using Realistic Mathematics Education in UK classrooms. In Centre for Mathematics Education, ....

Disnawati, H., \& Haning, F. O. (2019). Workshop Penggunaan Media Pembelajaran Berbasis Sampah dan Barang Bekas Bagi Guru MIN TTU. 2, 38-44.

Fertilia Ikashaum, Tina Yunarti, S. S. (2019). PERBANDINGAN KEMAMPUAN REPRESENTASI MATEMATIS SISWA ANTARA MODEL PEMBELAJARAN TTW DAN TPS. 1-14. https://doi.org/10.16043/j.cnki.cfs.2019.15.130

Holisin, iis. (2007). Pembelajaran Matematika Realistik. Didaktis, 5(3), 45-49.

Pika Merliza dan Heri Retnawati. (2018). Continuing Professional Development (CPD) for Juinior High School Mathematics Teachers: an evaluation study. ReiD. 79-93.

Putri, R. (2016). Journal of Non-Formal Education and. Journal of Nonformal Education and Community Empowerment, 5(1), 9-15.

Siahaan, friska b. (2006). Matematika Realistik.pdf. Jurnal Ilmiah, Vol. 08, pp. 36-39. Soviawati, E. (2011). Pendekatan Matematika Realistik (PMR) untuk Meningkatkan Kemampuan Berfikir Siswa di Tingkat Sekolah Dasar. Jurnal Penelitian Pendidikan, Edisi $\operatorname{Khus(2),~80-85.~}$ 
Volume 3, Nomor 1, Februari 2020

Toyiba, N. F. (2016). Pengaruh Strategi pembelajaran Aktif Terhadap hasil belajar pada Madrasah Ibtidaiyah. Pendidikan Guru Madrasah Ibtidaiyah, 1(2), 929-930.

Wibowo, A. (2017). Pengaruh pendekatan pembelajaran matematika realistik dan saintifik terhadap prestasi belajar, kemampuan penalaran matematis dan minat belajar. Jurnal Riset Pendidikan Matematika, 4(1), 1. https://doi.org/10.21831/jrpm.v4i1.10066

Wulantina, E., \& Maskar, S. (2019). Pengembangan Bahan Ajar Matematika Berbasis Lampungnese Etnomatematics, Development of Material Based on Lampungnese Etnomatematics. 09.9(2),71-78. 